\section{CHWIEJNYM KROKIEM W STRONĘ KULTURY} CHLOPSKIEJ

Iwański, P. (2016). Czy kultura ludowa/wiejska/chtopska to temat wart jeszcze rozmowy? Busko Zdrój: Wydawnictwo Eudajmonia-Zdrój, ss. 114.

Zwykło się mawiać, że epoki ideowe dokonują autorefleksji i autoidentyfikacji dopiero u swojego schyłku. Jeśli rzeczywiście jest to prawdą, to dla tradycyjnej kultury chłopskiej nadszedł najwyższy czas na taką myśl. Bowiem czy jesteśmy $\mathrm{z}$ tego zadowoleni czy nie - agonia kultury ludowej w takiej formie, $w$ jakiej istniała ona w poprzednich wiekach, jest faktem. Niemniej jednak większość współczesnej polskiej antropologii nie wykazuje zainteresowania tradycyjną kultura chłopską, zupełnie tak, jakby pole badawcze zostało już gruntownie przebadane, albo na wnikanie w zagadnienie pozostało jeszcze dużo czasu. Jedną z prób poruszenia tego zagadnienia stanowi tekst Piotra Iwańskiego, doktora nauk filozoficznych (KUL) oraz absolwenta studiów rolniczych (ARwK) Czy kultura ludowa/wiejska/chłopska to temat wart jeszcze rozmowy? Stanowi on próbę odpowiedzi na tytułowe pytanie z perspektywy refleksji filozoficznej oraz aktualnej sytuacji społeczno-kulturowej. Szczególnie intrygujacy jest fakt, że autor, urodzony na wsi, posiada wykształcenie zarówno rolnicze, jak i humanistyczne. Stanowi więc $w$ jednej osobie swego rodzaju pomost pomiędzy ,wielkim” światem nauki, a „prostym” światem kultury ludowej.

Książka jest ponad stustronicową broszurą, napisaną żywym, wręcz gawędziarskim językiem i opatrzoną licznymi ilustracjami. Z naukowego punktu widzenia można by to uznać za wadę - tekst ma dość luźną formę, nieprecyzyjny aparat bibliograficzny, większość przedstawianych w nim rozumowań opartych jest na dowodach o charakterze anegdotycznym. Niemniej jednak sam Autor nie pretenduje do nazywania swojego tekstu wyczerpującą rozprawą czy też złożona monografia, przyjmujac skromne i raczej adekwatne określenie „rozprawki”. Nie oznacza to jednak, że tekst zupełnie nie jest wart uwagi profesjonalnego kulturoznawcy czy etnologa. Nie jest on naukowy w znaczeniu formy, precyzji i pewnych konwenansów, ale jest on naukowy wtedy, gdy naukowość pojmujemy jako stawianie istotnych pytań i poszukiwanie wniosków. Niektóre ze spostrzeżeń autora uważam za słuszne i warte do upowszechnienia. Konstrukcja publikacji jest klarowna: najpierw autor przedstawia motywacje, które skłoniły go do napisania tekstu. Jest to szczytna chęć wzbudzenia dyskusji na temat kultury ludowej (o stosowaniu tego pojęcia przez autora piszę poniżej) - przede wszystkim jej szans na przetrwanie oraz jej miejsca we współczesnym świecie. Następnie autor przechodzi do wskazania głównych - jego zdaniem podstaw i cech kultury ludowej. Łączy się to z szerszą refleksją na temat miejsca kultury w społeczeństwie - jej relacji wobec społeczność i funkcji, które wobec niego pełni. Prowadzi to do konkluzji oraz zachęty w stronę czytelnika, by sam również podjął refleksję nad zagadnieniem. Autor nie proponuje pełnej, wyczerpujacej odpowiedzi na postawione w tytule pytanie. Jedynie sygnalizuje swoje stanowisko (zasadniczo uznające tradycyjną kulturę ludową za byt, który w znacznej mierze już przeminął, jednakże jest warty pamięci, która może pełnić istotną funkcję społeczna), ale to w gestii czytelnika pozostawia ostateczny werdykt. Tekst kończy postscriptum, w którym autor rozważa stosunek Kościoła Katolickiego wobec kultury, a przede wszystkim pobożności, ludowej widząc w Kościele sojusznika tych fenomenów.

Nim jednak przejdę do wskazania tego, co moim zdaniem decyduje o wartości omawianej publikacji, chciałbym zwrócić uwagę na pewne mankamenty.

Za pierwszy z nich, w mojej opinii kluczowy, należy uznać nieprecyzyjność podstawowej terminologii. Już $\mathrm{w}$ tytule autor używa zamiennie terminów kultura ludowa, kultura wiejska i kultura chłopska. Problem w tym, że nie są to synonimy. Kultura ludowa to kultura, w uproszczeniu, 
nieelitarnej części społeczeństwa - zarówno wiejskiej jak i miejskiej. Kultura wiejska to kultura mieszkańców wsi, a na wsi mieszkali i pracowali przecież nie tylko chłopi, ale i np. uboga szlachta, która posiadała nieco inną od chłopów obyczajowość. Kultura chłopska - którą tak naprawde na myśli zdaje się mieć autor - to zaś kultura konkretnego stanu czy też grupy społeczno-zawodowej, a zarazem najwęższy spośród używanych tu trzech terminów. W równie nieprecyzyjny sposób autor posługuje się terminem ,kultura”. W samym tytule jak i większości przypadków zdaje się przezeń rozumieć ogół zwyczajów i dziedzictwa danej ludności, w innych zaś miejscach (np. s. 59) podaje ją jako jakiś byt zewnętrzny od człowieka, coś co jest jakimś oddzielnym od społeczności bytem, który wpływa na jednostki. Czasami także używa słowa „,kultura" w znaczeniu wartościującym (s. 67), co utrudnia przeprowadzenie obiektywnego, klarownego wywodu.

Drugim problemem jest uboga baza bibliograficzna tekstu. Owszem, autor deklaruje, że jego praca nie jest monografią, a więc nie należy wymagać od niego wyczerpującej bazy tekstowej. Iwański w swojej pracy przypisuje skromną pozycję. Jednakże nadmierne braki w lekturach powodują to, że niejednokrotnie zdaje się on wyważać otwarte drzwi. Podaje przesłanki, przeprowadza rozumowanie i... dochodzi do wniosków, które istnieją w literaturze przedmiotu od kilkudziesięciu lat. Szczególnie dotkliwy jest w mojej opinii brak odwołań do klasycznej monografii Daniela Olszewskiego Polska Kultura Religijna na Przetomie XIX i XX wieku. Dzięki oparciu się na niej autor mógłby $\mathrm{z}$ tego, co $\mathrm{w}$ jego tekście stanowi nieraz punkt dojścia, uczynić punkt wyjścia. Bez watpienia podwyższyłoby to walory pracy i umożliwiło dotarcie do nowych, odkrywczych konkluzji. Szczególnie, lecz nie wyłącznie, mam tu na myśli fragmenty tekstu dotyczące tradycyjnej mentalności i religijności chłopskiej (Olszewski 1996: 147-222)

Kolejnym problemem jest fakt, że pomimo licznych trafnych spostrzeżeń co do obecnego stanu kultury ludowej i prób jej „wskrzeszania” (o czym piszę także poniżej), autor zdaje się czasem przedstawiać jej położenie w zbyt czarnych barwach. Dla niego sytuacja jest właściwie przegrana lud, rozumiany jako nośnik kultury ludowej, odchodzi, a nikt właściwie się nim nie interesuje. W jego opinii próby ,wskrzeszenia” kultury ludowej maja zaś charakter instrumentalny i karykaturalny. W rzeczywistości jednak chyba nie jest aż tak źle. Tak zwany luźny i nieformalny ruch in crudo, złożony głównie $\mathrm{z}$ różnorakich operujących samodzielnie bądź w grupkach ludoznawców-entuzjastów, którzy często na własną rękę wnikają w świat kultury ludowej, dość prężnie się w Polsce rozwija i przyjmuje różne odcienie. $\mathrm{Z}$ zasady ma on charakter praktyczny, a nie teoretyczny - raczej nie tworzy się tekstów teoretycznych czy opracowań naukowych, lecz niejako włącza się w kulturę ludową, dając jej nowe, młodsze pokolenie, które śpiewa, tańczy czy gra na instrumentach, starając wzorować się na prawdziwych ludowych artystach i ich działalności czy też dochodząc do swoich wniosków poprzez wnikliwą analizę źródeł historycznych. Przykłady można mnożyć - od zainteresowanych polską tradycją religijnego śpiewu ludowego dr. Bartosza Izbickiego (współpracownik Instytutu Sztuki PAN, lider i założyciel zespołu Jerycho) czy Adama Struga (Monodia Polska) po trudniących się w praktyce muzyką taneczną Kapelę Brodów i wielu, wielu innych. Powstają także związane $\mathrm{z}$ tą tematyką wydarzenia, jak szczeciński Turniej Muzyków Prawdziwych. Być może nie jest więc aż tak źle, jak to widzi autor? Może jednak szczere i rozsądne zainteresowanie prawdziwą kulturą ludową powoli wzrasta, co daje pewną nadzieję?

Zadziwia także fakt, że choć autor omawia zagadnienia kultury ludowej, nie odnosi się bezpośrednio do jej utworów. Pojawiają się liczne wspomnienia dzieł Mickiewicza, Norwida czy Reymonta (szczególnie Pielgrzymki do Jasnej Góry) - słowem różnych twórców „kultury wysokiej”. Jednak chłopi we własnej osobie zasadniczo nie 
mają szansy się wypowiedzieć. Choć autor wyraźnie stara się unikać paternalizacji, nie dopuszcza ich do głosu. Pomimo licznych fragmentów, w których Iwański broni ich podmiotowości, nie przedstawia on ich myśli czytelnikowi - brakuje cytatów ze źródeł ich autorstwa. Szkoda, że nie wykorzystano chociażby takiego klasyka jak Pamiętniki włościanina pióra Jana Słomki, w których autor przedstawia wiele refleksji na temat przemian szeroko rozumianej kultury ludowej przełomu XIX i XX wieku (np. Słomka 1912: 223-246).

Last but not least, autor zdaje się przeceniać społeczny wpływ pozytywnego stanowiska instytucjonalnie pojmowanego Kościoła Katolickiego wobec kultury ludowej. Autor powołuje się w swoim tekście na stanowiska hierarchów, jednak nie przesądzają one o szerszej praktyce księży czy też innych animatorów życia parafii. Kluczowe elementy polskiej religijności ludowej, jak np. różnorakie pieśni nabożne (Olszewski 1996: 149-152), są w znacznej mierze wypierane, i to przy bierności (o ile nie poparciu) kleru i organistów. Istnieją oczywiście wyjatki, lecz nie decyduja one o całokształcie. W miejsce szerokiej gamy głębokich pieśni tradycyjnych coraz częściej wchodzi unifikacja i uproszczenie. Od czasów upowszechnienia kultury masowej (w tym religijnej) pochodzenia miejskiego na wsi oraz tzw. odnowy liturgicznej przeprowadzonej po Soborze Watykańskim II tradycyjne formy pobożności są często odrzucane ze wzgarda i niemalże wymieraja wraz ze starszymi pokoleniami. $Z$ resztą podobne tendencje zdarzały się i już wcześniej. W praktyce zazwyczaj nie próbuje się zrozumieć religijnej kultury ludowej, czy choćby podjąć próby adaptacji i pogłębienia jej form - zazwyczaj po prostu pozwala im się umrzeć, nieczęsto oferując coś prawdziwie głębokiego w zamian. Polskiemu ludowi zabrano (albo też pozwolono mu porzucić) jego tradycyjna religijność (która - dla jasności nie była przecież idealna), generalnie nie oferując w zamian niczego pełnowartościowego na równie szeroką skalę.

Tyle krytyki, chciałbym w tym miejscu przejść do wskazania walorów pracy, które w mojej opinii mimo wszystko decyduja o jej wartości.

Pierwszą z nich jest trzeźwy poza kilkoma wspomnianymi wyżej wyjątkami- ogląd sytuacji. Autor, choć sam z pochodzenia chłop, nie łudzi się - kultura ludowa de facto jest już reliktem przeszłości (s. 11). Jest w stanie, już jako naukowiec, uderzyć się w pierś i wskazać na to, że humaniści przez długi czas - o ile nie do dziś traktowali kulturę ludową pogardliwie, bądź co najmniej paternalistycznie (s. 11-12). I nie jest to czcza albo zbedna deklaracja. Ów głos uważam za niezwykle istotny i potrzebny, choć może i wybrzmiewał już nieraz. Temat kultury ludowej we współczesnym polskim dyskursie naukowym jest w znacznej mierze bagatelizowany. Do dziś na wielu uczelniach w Polsce jednym z tekstów wprowadzających w kulturę ludową jest Kultura Stefana Czarnowskiego, z lektury której wynika w znacznej mierze karykaturalny, jednostronny i pogardliwy wizerunek obyczajowości ludu (por. Czarnowski 2005: 102-127), w znacznej mierze niezgodny ze stanem faktycznym (por. Olszewski 1996: 135-146). Do dziś trwa więc reprodukowanie klasizmu, niechęci czy chociażby obojętności wobec kultury zdecydowanej większości naszych przodków w sposób daleko odbiegający od naukowości. Dlatego każdy stanowczy głos protestu w tej materii uważam za cenny i istotny.

Kolejnym walorem pracy jest zauważenie drugiego bieguna skrajności - czczej i powierzchownej fascynacji kulturą ludową, chłopomanii (w tym, jak to ostatnio ujał znawca tematu Roch Sulima, „nowej chłopomanii"; Księżyk, Sulima 2018) pod różnymi postaciami. Dzięki temu autor kreuje przed czytelnikiem użyteczną typologie postaw wobec kultury ludowej - od pogardy i paternalizmu, przez bezkrytyczne zauroczenie po zdrowy, trzeźwy ogląd. Zauważa to, że niemniej groźna dla kultury jest pogarda, jak i jej „ulukrowanie”, bezrefleksyjna fascynacja oderwana od wnikliwości. Niemniej krytycznie postrzega Iwański czysto estetyczne podejście do kultury ludowej, które pomija całkowicie jej ideowe, społeczne $\mathrm{i}$ materialne podstawy (jakby 
powiedział Marks - bazę; s. 87-88). Wobec wspomnianej wyżej powolnej popularyzacji różnorakich tendencji zainteresowania kulturą ludową - wspomnianego już in crudo, ale także mniej profesjonalnych - ów otrzeźwiający głos jest bardzo cenny.

W świetle dwóch powyższych zalet, uważam tekst Piotra Iwańskiego za interesujący, wart lektury i przysparzający wartościowych spostrzeżeń. Nie brakuje mu mankamentów, jednakże autor nie tworzy pozorów, że napisał monografię zagadnienia. Należy go czytać z pewnym krytycyzmem, lecz być i otwartym na to, co wśród defektów okazuje się walorem. W lekkiej, popularyzatorskiej wręcz formie, podejmuje kluczowe zagadnienia związane z kulturą ludową, które niestety już dość rzadko są poruszane zarówno w środowisku akademickim, jak i w szerszych kręgach. Tekst Piotra Iwańskiego stanowi więc ważny głos, lecz jest to poniekąd głos wołającego na puszczy. Jeśli potraktuje się jego utwór jako luźny esej czy też obszerny artykuł publicystyczny, w którym autor ma prawo podejść swobodniej do argumentacji i aparatu bibliograficznego, stanowi on dość wartościowy tekst. I - choć po drodze nie brakuje tu pewnych nieporadności, potknięć i mankamentów - wskazuje na istotne zjawiska, dochodzi do wartych rozpowszechnienia wniosków oraz zachęca do dalszej refleksji nad tym, jakże kluczowym dla antropologii czy polskiej tożsamości kulturowej, zagadnieniem.

\section{BIBLIOGRAFIA}

CZARNOWSKI, S. (2005). Kultura. Warszawa: Wydawnictwo Akademickie „Żak”. KSIĘŻYK, R., Sulima R. (2018). Nadchodzi nowa chtopomania. „Pismo: Magazyn Opinii”, 10 (październik 2018). Pozyskano z https://magazynpismo.pl/nadchodzi-nowachlopomania/

OLSZEWSKI, D. (1996). Polska Kultura Religijna na Przełomie XIX i XX Wieku. Warszawa: Instytut Wydawniczy Pax.

SŁomKA, J. (1912). Pamiętniki Włościanina: Od Pańszczyzny do Dni Dzisiejszych. Kraków: Krakowska Drukarnia Nakładowa. 